\title{
Effect of carbonate ion concentration and irradiance on calcification in planktonic foraminifera
}

\author{
F. Lombard ${ }^{1, *}$, R. E. da Rocha ${ }^{2}$, J. Bijma ${ }^{2}$, and J.-P. Gattuso ${ }^{3,4}$ \\ ${ }^{1}$ LSCE/IPSL, laboratoire CEA/CNRS/UVSQ, LSCE-Vallée, Bât. 12, avenue de la Terrasse, \\ 91198 Gif-sur-Yvette CEDEX, France \\ ${ }^{2}$ Alfred Wegener Institute for Polar and Marine Research, Am Handelshafen 12, 27570 Bremerhaven, Germany \\ ${ }^{3}$ INSU-CNRS, Laboratoire d'Océanographie de Villefranche-sur-mer, B.P. 28, 06234 Villefranche-sur-mer Cedex, France \\ ${ }^{4}$ UPMC University of Paris 06, Observatoire Océanologique de Villefranche-sur-mer, 06230 Villefranche-sur-mer, France \\ * currently at: DTU Aqua, Technical University of Denmark, Kavalergården 6, 2920 Charlottenlund, Denmark
}

Received: 27 July 2009 - Published in Biogeosciences Discuss.: 1 September 2009

Revised: 21 December 2009 - Accepted: 23 December 2009 - Published: 19 January 2010

\begin{abstract}
The effect of carbonate ion concentration $\left(\left[\mathrm{CO}_{3}^{2-}\right]\right)$ on calcification rates estimated from shell size and weight was investigated in the planktonic foraminifera Orbulina universa and Globigerinoides sacculifer. Experiments on G. sacculifer were conducted under two irradiance levels ( 35 and $335 \mu$ mol photons $\mathrm{m}^{-2} \mathrm{~s}^{-1}$ ). Calcification was ca. $30 \%$ lower under low light than under high light, irrespective of the $\left[\mathrm{CO}_{3}^{2-}\right]$. Both $O$. universa and G. sacculifer exhibited reduced final shell weight and calcification rate under low $\left[\mathrm{CO}_{3}^{2-}\right]$. For the $\left[\mathrm{CO}_{3}^{2-}\right]$ expected at the end of the century, the calcification rates of these two species are projected to be 6 to $13 \%$ lower than the present conditions, while the final shell weights are reduced by 20 to $27 \%$ for $O$. universa and by 4 to $6 \%$ for $G$. sacculifer. These results indicate that ocean acidification would impact on calcite production by foraminifera and may decrease the calcite flux contribution from these organisms.
\end{abstract}

\section{Introduction}

Due mostly to human activities, the atmospheric carbon dioxide $\left(\mathrm{CO}_{2}\right)$ partial pressure is currently increasing. Depending on the socio-economic scenarios, the $\mathrm{CO}_{2}$ level will reach 490 to 1250 ppmv by 2100 (Prentice et al., 2001). About 25\% of the total anthropogenic $\mathrm{CO}_{2}$ emissions have been absorbed by the ocean (Sabine et al., 2004). However,

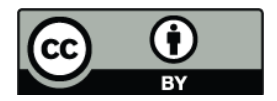

Correspondence to: F. Lombard (fla@aqua.dtu.dk) absorption of large quantities of atmospheric carbon implies changes in the carbonate system equilibrium, notably a decrease in $\mathrm{pH}$ and carbonate ion concentration $\left(\left[\mathrm{CO}_{3}^{2-}\right]\right)$. $\mathrm{pH}$ has already decreased by 0.1 units compared to pre-industrial values and will further decrease by 0.3 to 0.4 units by 2100 (Feely et al., 2004; Orr et al., 2005). Such changes may significantly influence the calcification rates of various organisms. Previous studies have reported that ocean acidification negatively impacts calcification in coccolithophores, pteropods, corals, and commercial shellfish (e.g., Riebesell et al., 2000; Leclercq et al., 2000; Gazeau et al., 2007; Comeau et al., 2009), but some species or strains may be unaffected at elevated $p \mathrm{CO}_{2}$ (e.g., Iglesias-Rodriguez et al., 2008). Reducing the calcification rate of planktonic organisms can have opposite effects on the carbon cycle. Firstly, it decreases the positive feedback of calcification on atmospheric $\mathrm{CO}_{2}$ (Gattuso et al., 1999; Wolf-Gladrow et al., 1999). Secondly, ocean acidification will decrease the role of ballast that calcium carbonate has by facilitating the export of organic matter to the deep ocean (Armstrong et al., 2002; Klaas and Archer, 2002). Understanding the possible effects of ocean acidification, therefore, requires investigating the response of the major calcifying organisms.

Planktonic foraminifera are widespread calcifying protozoa, responsible for $32-80 \%$ of the global deep-ocean calcite fluxes (Schiebel, 2002). Moy et al. (2009) reported that the modern shell weight of G. bulloides is 30 to $35 \%$ lower than that measured from the sediments. They attributed the difference to reduced calcification in response to ocean acidification. Several experimental results also indicate that ocean acidification can impact planktonic foraminifera notably by

Published by Copernicus Publications on behalf of the European Geosciences Union. 
Table 1. G. sacculifer initial and final mean size $\left(S_{\mathrm{i}}\right.$ and $\left.S_{\mathrm{f}}\right)$, final weight $\left(W_{\mathrm{f}}\right)$ and estimated initial weight $\left(W_{\mathrm{i}}\right)$, duration of the experiment from collection to gametogenesis $(\Delta t)$ and mean weight increase $(\Delta w)$ under the different $\left[\mathrm{CO}_{3}^{2-}\right]$, total alkalinity (TA), pH and irradiance levels. See Table A1 of Russel et al. (2004) for similar information on O. universa.

\begin{tabular}{|c|c|c|c|c|c|c|c|c|c|}
\hline Light & $\begin{array}{r}{\left[\mathrm{CO}_{3}^{2-}\right]} \\
\left(\mu \mathrm{mol} \mathrm{kg}^{-1}\right)\end{array}$ & $\begin{array}{r}\text { TA } \\
\left(\mu \mathrm{Eq} \mathrm{kg}^{-1}\right)\end{array}$ & $\mathrm{pH}$ & $\begin{array}{r}S_{\mathrm{i}} \\
(\mu \mathrm{m})\end{array}$ & $\begin{array}{r}S_{\mathrm{f}} \\
(\mu \mathrm{m})\end{array}$ & $\begin{array}{r}W_{\mathrm{f}} \\
(\mu \mathrm{g})\end{array}$ & $\begin{array}{l}\Delta t \\
\text { (d) }\end{array}$ & $\begin{array}{r}W_{\mathrm{i}} \\
(\mu \mathrm{g})\end{array}$ & $\begin{array}{l}\Delta w \\
(\mu \mathrm{g})\end{array}$ \\
\hline \multirow{8}{*}{ HL } & 71.9 & 2055 & 7.66 & 372 & 625 & 33.8 & 6.1 & 14.5 & 19.3 \\
\hline & 124 & 2165 & 7.90 & 388 & 699 & 49.0 & 7.0 & 16.0 & 33.0 \\
\hline & 139 & 2204 & 7.95 & 430 & 691 & 47.6 & 6.7 & 19.0 & 28.5 \\
\hline & 233 & 2365 & 8.21 & 380 & 662 & 47.6 & 7.4 & 15.6 & 32.0 \\
\hline & 455 & 2680 & 8.53 & 399 & 667 & 57.1 & 6.3 & 16.6 & 40.5 \\
\hline & 504 & 2741 & 8.59 & 386 & 678 & 51.4 & 6.8 & 15.4 & 36.1 \\
\hline & 566 & 2827 & 8.64 & 401 & 637 & 48.5 & 5.5 & 17.0 & 31.5 \\
\hline & Mean & & & 393 & 664 & 48.2 & 6.6 & 16.2 & 31.9 \\
\hline \multirow{8}{*}{ LL } & 71.9 & 2055 & 7.66 & 384 & 509 & 20.1 & 4.3 & 15.0 & 5.1 \\
\hline & 124 & 2165 & 7.90 & 366 & 507 & 20.3 & 4.2 & 14.3 & 6.0 \\
\hline & 139 & 2204 & 7.95 & 446 & 601 & 26.4 & 3.7 & 21.0 & 5.4 \\
\hline & 233 & 2365 & 8.21 & 403 & 585 & 37.9 & 5.2 & 17.5 & 20.5 \\
\hline & 455 & 2680 & 8.53 & 397 & 541 & 29.2 & 4.5 & 16.3 & 12.9 \\
\hline & 504 & 2741 & 8.59 & 379 & 503 & 20.8 & 3.9 & 14.7 & 6.0 \\
\hline & 566 & 2827 & 8.64 & 406 & 528 & 28.7 & 4.1 & 16.9 & 11.8 \\
\hline & Mean & & & 399 & 550 & 29.1 & 4.5 & 16.8 & 12.3 \\
\hline \multicolumn{2}{|c|}{ Combined $\mathrm{HH}+\mathrm{LL}$} & & & 396 & 603 & 38.0 & 5.5 & 16.5 & 21.4 \\
\hline
\end{tabular}

reducing their shell thickness and weight (Bijma et al., 1999; Russell et al., 2004). However, these results were obtained as by-products of geochemical studies focusing on shell composition and did not provide any quantitative estimates of calcification rates.

In this article, the results of different geochemical experiments are reanalysed in order to provide quantitative estimates of the effect of ocean acidification on foraminiferal calcification. We focus on two widespread species of planktonic foraminifera that both harbour photosymbionts: Orbulina universa and Globigerinoides sacculifer.

\section{Material and methods}

Data used in this investigation originate from two previous studies. The first study was conducted during summer 2000 on Orbulina universa in Catalina Island, California (Russell et al., 2004) and the second study targeted Globigerinoides sacculifer in Puerto Rico in the summer of 2006 (R. da Rocha, A. Kuroyanagi, G.-J. Reichart, and J. Bijma, unpublished data). In both cases, individuals were collected by scuba-divers, and grown in the laboratory until gametogenesis. They were fed regularly (every third day, starting on the day of collection) and kept under a 12:12 h light:dark cycle. $O$. universa was cultured under high irradiance ( 300 to $400 \mu \mathrm{mol}$ photons $\mathrm{m}^{-2} \mathrm{~s}^{-1}$ ) whereas $G$. sacculifer was grown under high (HL) and low (LL) irradiances (335 and $35 \mu \mathrm{mol}$ photons $\mathrm{m}^{-2} \mathrm{~s}^{-1}$, respectively). $\left[\mathrm{CO}_{3}^{2-}\right]$ was manipulated by adding $\mathrm{NaOH}$ or $\mathrm{HCl}$ to filtered sea water. Foraminifera were kept in this modified seawater in closed borosilicate glass culture vessels of $125 \mathrm{ml}$, with no headspace to prevent exchange with atmospheric $\mathrm{CO}_{2}$.

The carbonate chemistry of the solutions was analysed by measuring alkalinity via Gran titration using a Metrohm open-cell autotitrator (mean precision: $10 \mu \mathrm{Eq} \mathrm{kg}^{-1}$ ), that was calibrated against certified reference material provided by $\mathrm{A}$. Dickson. Seawater $\mathrm{pH}$ and culture media $\mathrm{pH}$ were determined potentiometrically and calibrated with standard NIST buffers. The $\mathrm{pH}$ values are reported on the NBS scale. Alkalinity and $\mathrm{pH}$ measured at the start and termination of the experiments were used to calculate initial and final carbonate chemistry using CO2SYS (Lewis and Wallace, 1998) and the dissociation constants of Mehrbach et al. (1973) refitted by Dickson and Millero (1987).

Globigerinoides sacculifer was grown at $26( \pm 1)^{\circ} \mathrm{C}$ in seawater with a salinity of $36.2( \pm 0.2)$. Data include measurements of the initial and final size $(\mu \mathrm{m})$, the survival time $(\Delta t$; days from collection to gametogenesis), and final weight of the shell $\left(W_{\mathrm{f}} ; \mu \mathrm{g}\right)$ of each specimen measured prior to isotopic analysis. Only individuals that underwent gametogenesis and grew at least one chamber were used for subsequent analysis. The initial shell weight $\left(W_{\mathrm{i}} ; \mu \mathrm{g}\right)$ was estimated from initial shell size and using the measured shell size vs. weight regression obtained under "ambient" $\left[\mathrm{CO}_{3}^{2-}\right]$ $\left(233 \mu \mathrm{mol} \mathrm{kg}^{-1}\right.$, Fig. 1, Table 1). The initial and final organic carbon weight of each foraminifera was calculated using a conversion factor $\left(0.089 \mathrm{pg} \mathrm{C} \mathrm{m}^{-3}\right.$; Michaels et al., 

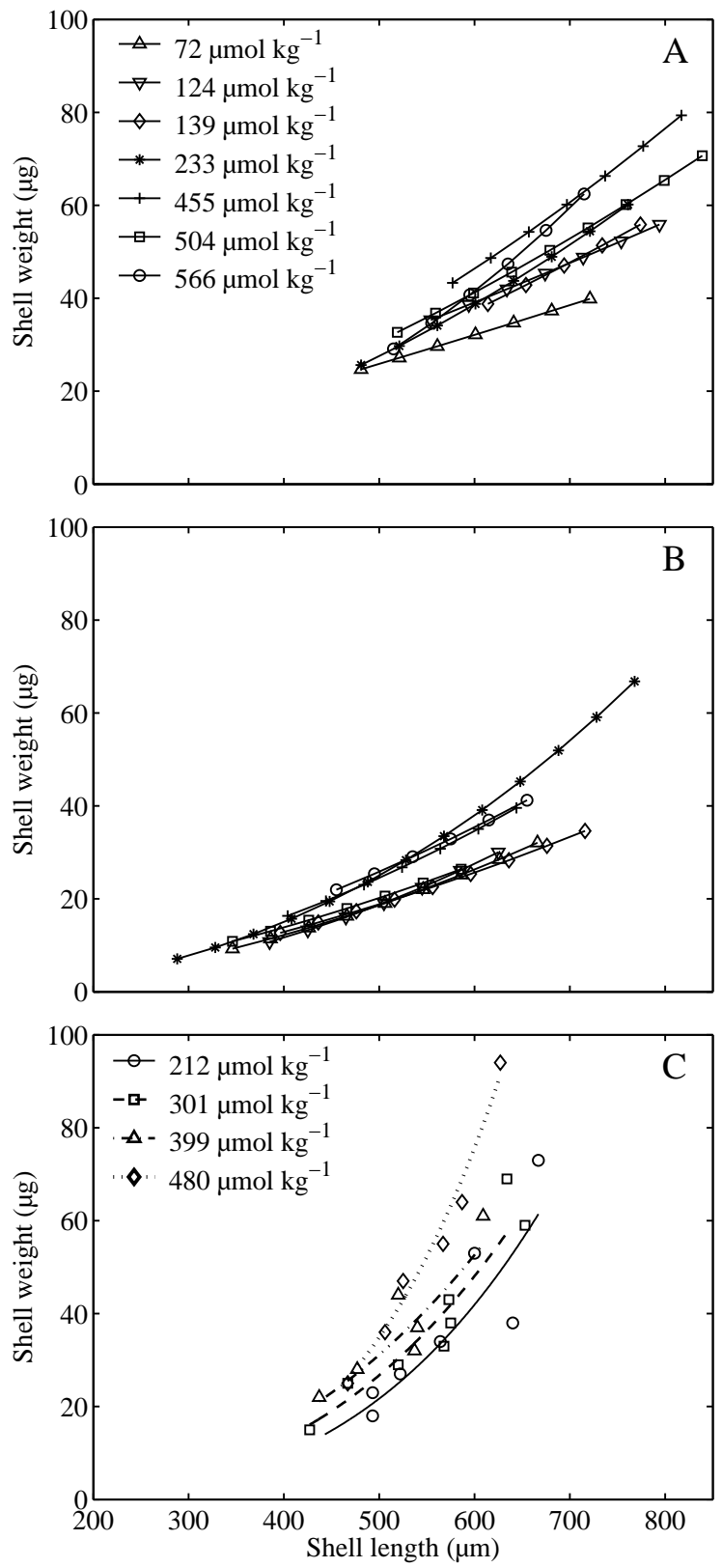

Fig. 1. Length-weight relationships obtained for different $\left[\mathrm{CO}_{3}^{2-}\right]$ conditions for G. sacculifer under HL (A) and LL (B) and O. universa $(\mathbf{C})$. For a better view, regression lines are only shown for G. sacculifer. Parameters of the regression lines are indicated in Table 2 .

1995) assuming a spherical shells shape. The geometric average weight $\left(W_{\text {org }} ; \mu \mathrm{g} C\right)$ was then calculated. In order to estimate calcification rates independently from the individual size, it was normalized per unit of cytoplasmic carbon $\left(C ; \mu \mathrm{g} \mu \mathrm{g} \mathrm{C} \mathrm{C}^{-1} \mathrm{~d}^{-1}\right)$ :

$C=\frac{W_{\mathrm{f}}-W_{\mathrm{i}}}{W_{\mathrm{org}} \Delta t}$
Data for $O$. universa were taken directly from Table A1 of Russell et al. (2004) and only the results obtained at $22^{\circ} \mathrm{C}$ were used. Results from their experiment I and II, even though similar, were kept separate because the number of specimens per sample was different. The average shell length $(\mu \mathrm{m})$ and weight $(\mu \mathrm{g})$ of mature specimens were used to estimate the length-weight relationship for each condition. Unfortunately, critical measurements, such as initial size or survival time, were not reported. The survival time in the laboratory $(\Delta t)$ was assumed to be 7.4 days because this was the mean survival time at $22{ }^{\circ} \mathrm{C}$ observed in experiments carried out at the Catalina Island laboratory (Lombard et al., 2009). All specimens grew a spherical chamber, which represented 95\% of the final shell weight (Lea et al., 1995; Russell et al., 2004). The initial (pre-spherical) weight of the shell $\left(W_{i}\right)$ was, therefore, estimated to represent $5 \%$ of the final weight. The organic carbon weight $\left(W_{\text {org }}\right)$ was calculated from the final size of adult $O$. universa (spherical form) and the spe-

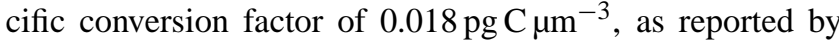
Michaels et al. (1995). The calcification rate was then calculated as described in Eq. (1).

\section{Results}

In the $G$. sacculifer experiments, the average initial size was $396( \pm 92) \mu \mathrm{m}$ with a minimum size of $190 \mu \mathrm{m}$ and a maximum size $716 \mu \mathrm{m}$ (Table 1). Irradiance had a strong effect on both $\Delta t$ and final size. Under the LL condition, the individuals reproduced, on average, two days earlier and at a smaller size (about $100 \mu \mathrm{m}$ less) than under HL. The different $\left[\mathrm{CO}_{3}^{2-}\right]$ conditions had little or no effect on $\Delta t$ and the final size of the organisms (Table 1). Only the final shell weight seemed to be influenced by $\left[\mathrm{CO}_{3}^{2-}\right]$, and individuals had generally heavier shells when grown under high $\left[\mathrm{CO}_{3}^{2-}\right]$ conditions ( $t$-test, $P<0.001$ in all cases). This result indicates that the shell thickness is influenced by $\left[\mathrm{CO}_{3}^{2-}\right]$ but not the general growth pattern. However, since $\Delta t$ and the initial and final shell sizes influenced the final shell weight, a better indicator of calcification that is independent of these parameters must be used.

The relationships between shell size and weight (Fig. 1, Table 2) highlight the role of $\left[\mathrm{CO}_{3}^{2-}\right]$, yet these shell sizeweight relationships were still influenced by $\Delta t$ and the initial size of the individuals. The shell length-weight relationships were similar between HL and LL but differed under ambient $\left[\mathrm{CO}_{3}^{2-}\right]$ condition $\left(233 \mu \mathrm{mol} \mathrm{kg}{ }^{-1}\right)$. The HL and $\mathrm{LL}$ data at ambient $\left[\mathrm{CO}_{3}^{2-}\right]$ were, therefore, combined and used to estimate the initial shell weight of individuals based on the initial shell size. On average, the initial shell weight represented $35 \%$ of the final weight under HL and $61 \%$ under LL. Consequently, the shell size-weight differences observed among the various $\left[\mathrm{CO}_{3}^{2-}\right]$ conditions are larger under HL conditions (Fig. 1a) than under LL conditions (Fig. 1b). For G. sacculifer, under all conditions, the 
Table 2. Parameters of relationships between length $(L)$ and shell weight $(W)$ obtained for the different species, under different $\left[\mathrm{CO}_{3}^{2-}\right]$ and light conditions for $G$. sacculifer. All the relationships are expressed as $W=a L^{b}$. Covariance analyses on log-transformed data were used to test the effect of $\left[\mathrm{CO}_{3}^{2-}\right]$ and irradiance on the final shell weight. ${ }^{*}: P<0.01$; $^{* *}: P<0.005 ;{ }^{* * *}: P<0.0001$.

\begin{tabular}{|c|c|c|c|c|c|c|c|c|}
\hline \multirow[b]{2}{*}{ Species } & \multirow[b]{2}{*}[\mathrm{CO}_{3}^{2-}]{} & \multirow[b]{2}{*}{ Light } & \multirow[b]{2}{*}{$a$} & \multirow[b]{2}{*}{$b$} & \multirow[b]{2}{*}{$R^{2}$} & \multirow[b]{2}{*}{$n$} & \multicolumn{2}{|c|}{ Test HL $\neq \mathrm{LL}$} \\
\hline & & & & & & & $a$ & $b$ \\
\hline \multirow[t]{2}{*}{ G. sacculifer } & \multirow[b]{2}{*}{71.9} & $\mathrm{HL}$ & $1.67 \times 10^{-2}$ & 1.18 & 0.81 & 11 & \multirow[b]{2}{*}{ * } & \multirow[b]{2}{*}{$\mathrm{ns}$} \\
\hline & & LL & $1.44 \times 10^{-4}$ & 1.89 & 0.85 & 7 & & \\
\hline \multirow[t]{2}{*}{ G. sacculifer } & \multirow[b]{2}{*}{124} & $\mathrm{HL}$ & $1.13 \times 10^{-2}$ & 1.27 & 0.29 & 8 & \multirow[b]{2}{*}{ * } & \multirow[b]{2}{*}{ ns } \\
\hline & & LL & $3.55 \times 10^{-5}$ & 2.12 & 0.73 & 12 & & \\
\hline \multirow{2}{*}{ G. sacculifer } & \multirow[b]{2}{*}{139} & HL & $1.56 \times 10^{-3}$ & 1.58 & 0.54 & 11 & \multirow[b]{2}{*}{$* * *$} & \multirow[b]{2}{*}{ ns } \\
\hline & & LL & $4.95 \times 10^{-4}$ & 1.70 & 0.89 & 18 & & \\
\hline \multirow{3}{*}{ G. sacculifer } & \multirow{3}{*}{233} & HL & $2.63 \times 10^{-4}$ & 1.86 & 0.62 & 20 & \multirow{3}{*}{$\mathrm{ns}$} & \multirow{3}{*}{ ns } \\
\hline & & LL & $1.66 \times 10^{-5}$ & 2.29 & 0.91 & 34 & & \\
\hline & & $\mathrm{HL}+\mathrm{LL}$ & $3.60 \times 10^{-5}$ & 2.17 & 0.87 & 54 & & \\
\hline \multirow{2}{*}{ G. sacculifer } & \multirow{2}{*}{455} & HL & $6.71 \times 10^{-4}$ & 1.74 & 0.56 & 13 & \multirow[b]{2}{*}{$* * *$} & \multirow[b]{2}{*}{ ns } \\
\hline & & LL & $1.87 \times 10^{-4}$ & 1.90 & 0.86 & 13 & & \\
\hline \multirow[t]{2}{*}{ G. sacculifer } & \multirow{2}{*}{504} & HL & $1.41 \times 10^{-3}$ & 1.61 & 0.73 & 15 & \multirow{2}{*}{$* * *$} & \multirow[b]{2}{*}{ ns } \\
\hline & & LL & $5.65 \times 10^{-4}$ & 1.69 & 0.66 & 12 & & \\
\hline \multirow[t]{2}{*}{ G. sacculifer } & & $\mathrm{HL}$ & $1.41 \times 10^{-5}$ & 2.33 & 0.9 & 13 & & \\
\hline & 566 & LL & $5.57 \times 10^{-4}$ & 1.73 & 0.84 & 20 & $* *$ & ns \\
\hline Test within LL & & & $* * *$ & ns & & & & \\
\hline Test within HL & & & $* * *$ & ns & & & & \\
\hline O. universa & 212 & & $3.92 \times 10^{-9}$ & 3.61 & 0.84 & 7 & & \\
\hline O. universa & 301 & & $5.44 \times 10^{-8}$ & 3.22 & 0.93 & 8 & & \\
\hline O. universa & 399 & & $5.25 \times 10^{-7}$ & 2.89 & 0.85 & 6 & & \\
\hline O. universa & 480 & & $1.17 \times 10^{-10}$ & 4.25 & 0.98 & 6 & & \\
\hline Test within $O . u$ & iniversa & & $* * *$ & ns & & & & \\
\hline
\end{tabular}

exponents $b$ of the regressions were not significantly different at various $\left[\mathrm{CO}_{3}^{2-}\right]$, whereas $a$ is significantly different (covariance analysis on log-transformed data; Table 2). Under $\mathrm{HL}$, for a given size, G. sacculifer grown at low $\left[\mathrm{CO}_{3}^{2-}\right]$ (72, 124 and $139 \mu \mathrm{mol} \mathrm{kg}^{-1}$ ) were lighter than at "ambient" $\left(233 \mu \mathrm{mol} \mathrm{kg}^{-1}\right)$ and $504 \mu \mathrm{mol} \mathrm{kg}{ }^{-1}$ conditions. The heaviest weights for $G$. sacculifer under HL were achieved at high $\left[\mathrm{CO}_{3}^{2-}\right]$ conditions $\left(455\right.$ and $\left.566 \mu \mathrm{mol} \mathrm{kg}^{-1}\right)$. Only two weight groups can be identified at LL with heavier shells grown at $\left[\mathrm{CO}_{3}^{2-}\right]$ of 233,455 , and $566 \mu \mathrm{mol} \mathrm{kg}^{-1}$ and lighter shells produced at concentrations of 72, 124, 139 and, surprisingly, $504 \mu \mathrm{mol} \mathrm{kg}{ }^{-1}$. In both irradiance conditions, the difference in weight as a function of increasing $\left[\mathrm{CO}_{3}^{2-}\right]$ was greater for the largest specimens. Similar observations were made for $O$. universa. The exponents of all relationships were not significantly different and can be approximated by a mean exponent $b$ of 3.42 , but the parameter $a$ is significantly different for the different relationships (Table 2). O. universa shell weights increased with increasing $\left[\mathrm{CO}_{3}^{2-}\right]$ (Fig. 1c).

Figure 2 shows the shell weight as a function of $\left[\mathrm{CO}_{3}^{2-}\right]$ (Table 2, Fig. 1) for different ranges of shell size. Since the initial weight of $G$. sacculifer accounts for a large part of the final weight, only a final size of $700 \mu \mathrm{m}$ was considered, in order to minimize the pre-culture (field-grown) contribution to shell mass. Within a similar size range, the final shell weight for both $G$. sacculifer and $O$. universa increased significantly with increasing $\left[\mathrm{CO}_{3}^{2-}\right]$. However, due to their different modes of calcification growth (final sphere formation vs. consecutive chamber additions), the $\left[\mathrm{CO}_{3}^{2-}\right]$ effect was greater for $O$. universa compared to G. sacculifer, greater for large individuals of $O$. universa and greater under HL than under LL for G. sacculifer. Indeed, the effect of $\left[\mathrm{CO}_{3}^{2-}\right]$ was not significant for G. sacculifer in LL conditions. However, the final shell weight of $G$. sacculifer obtained in LL was 20 to $26 \%$ lower than under HL. This difference means that field-grown contribution to shell mass was higher in LL conditions and may have hidden calcification differences. Calcification rates normalized per unit biomass were calculated from previous weights and survival time measurements. The biomass-normalized rate of calcification declined significantly with decreasing $\left[\mathrm{CO}_{3}^{2-}\right]$ for both species (Fig. 3). The relationships between calcification $\left(C ; \mu \mathrm{g} \mathrm{d}^{-1} \mu \mathrm{gC}^{-1}\right)$ and $\left[\mathrm{CO}_{3}^{2-}\right]\left(\mu \mathrm{mol} \mathrm{kg}{ }^{-1}\right)$ can be written as ( \pm standard deviation): 

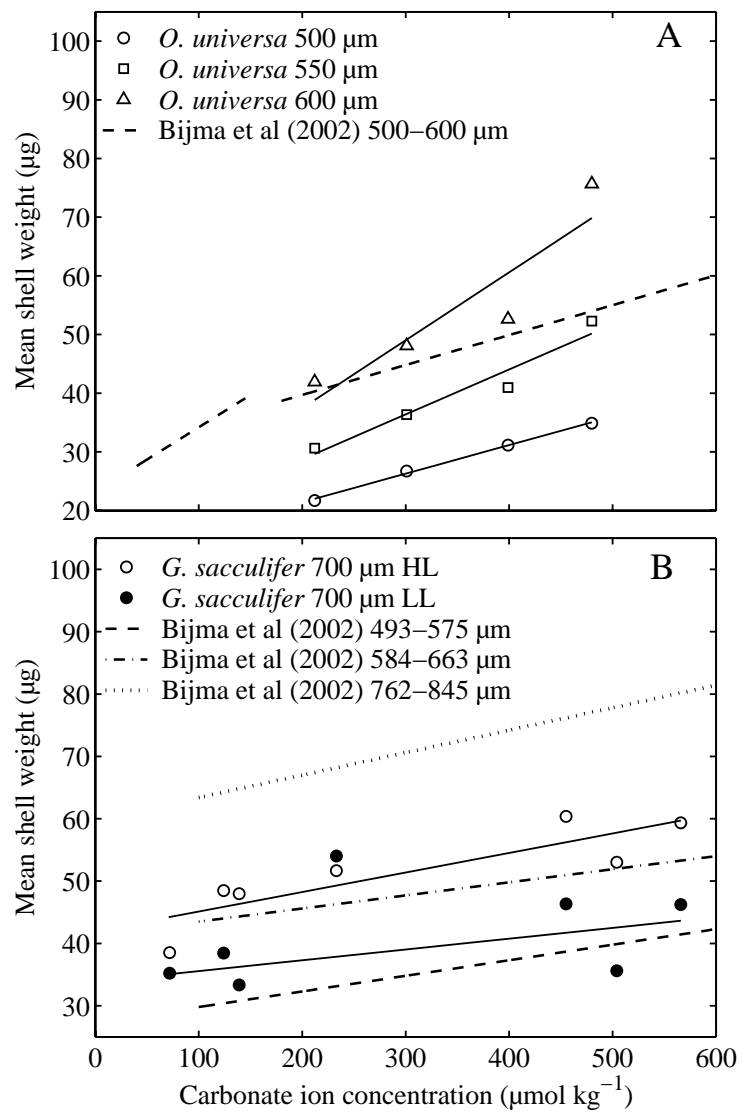

Fig. 2. (A) and G. sacculifer (B) as a function of the carbonate ion concentration for different final shell sizes. The regression lines correspond to the following relationships with the corresponding confidence intervals: $W_{\mathrm{f}}=0.049( \pm 0.002)\left[\mathrm{CO}_{3}^{2-}\right]+11.67( \pm 0.67), R^{2}=0.99$ for $500 \mu \mathrm{m}$ O. universa; $W_{\mathrm{f}}=0.077( \pm 0.001)\left[\mathrm{CO}_{3}^{2-}\right]+13.4( \pm 4.8), \quad R^{2}=0.94$ for $550 \mu \mathrm{m} O$. universa; $W_{\mathrm{f}}=0.116( \pm 0.04)\left[\mathrm{CO}_{3}^{2-}\right]+14.3( \pm 8.6)$, $R^{2}=0.83$ for $600 \mu \mathrm{m} \quad O$. universa; $W_{\mathrm{f}}=0.031( \pm 0.008)$ $\left[\mathrm{CO}_{3}^{2-}\right]+41.9( \pm 2.9), \quad R^{2}=0.73$ for $700 \mu \mathrm{m}$ G. sacculifer in $\mathrm{HL}$ and $W_{\mathrm{f}}=0.017( \pm 0.009)\left[\mathrm{CO}_{3}^{2-}\right]+33.8( \pm 3.6), R^{2}=0.33$ for $700 \mu \mathrm{m}$ G. sacculifer in LL. All relationships have slopes significantly different from zero $(P<0.02)$ except for $G$. sacculifer $\mathrm{LL}$ for which the low regression significance does not allow to perform this test. The slopes are not significantly different (covariance analysis; $P>0.1$ ) whereas the intercepts are significantly different $(P<0.0001)$. Similar relationships obtained for the same species (Bijma et al., 2002) were added for comparison.

$C=6.5( \pm 2.3) \cdot 10^{-4}\left[\mathrm{CO}_{3}^{2-}\right]+0.67( \pm 0.08)$

$R^{2}=0.07$ for G. sacculifer $(\mathrm{HL})$

$C=3.4( \pm 2.7) \cdot 10^{-4}\left[\mathrm{CO}_{3}^{2-}\right]+0.47( \pm 0.08)$

$R^{2}=0.03$ for $G$. sacculifer $(\mathrm{LL})$

$C=2.70( \pm 0.97) \cdot 10^{-3}\left[\mathrm{CO}_{3}^{2-}\right]+1.3( \pm 0.34)$

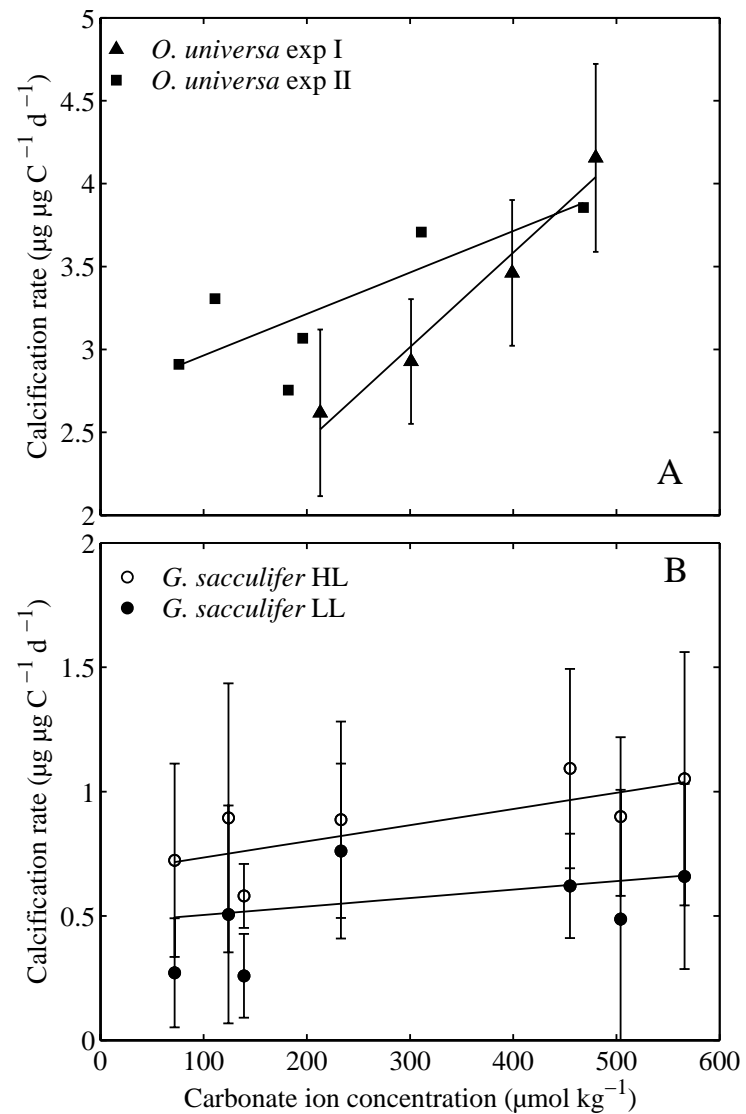

Fig. 3. Effect of the carbonate ion concentration on the biomassnormalized rates of calcification in $O$. universa (A) and $G$. sacculifer (B) calcification rates. Error bars indicate the standard deviation observed between the different foraminifera individuals within similar conditions.

$R^{2}=0.04$ for $O$. universa $(\exp . \mathrm{I})$

$C=2.47( \pm 0.89) \cdot 10^{-3}\left[\mathrm{CO}_{3}^{2-}\right]+2.7( \pm 0.23)$

$R^{2}=0.04$ for $O$. universa (exp. II)

Despite the large variability, which led to low $R^{2}$, the slopes of all relationships were significantly different from zero $\left(F_{1.89}=7.48 ; \quad P=0.0075\right.$ for $G$. sacculifer $\mathrm{HL}$; $F_{1.102}=6.36 ; P=0.0134$ for $G$. sacculifer $L L ; F_{1.25}=34.2$; $P<0.0001$ for $O$. universa experiment I and $F_{1,4}=8.3$; $P=0.0045$ for $O$. universa experiment II).

Due to the calcification of its large spherical chamber, the calcification rate of $O$. universa was 2.5 to 4 times larger than for G. sacculifer (HL). The calcification of G. sacculifer in LL conditions was reduced by $30 \%$ on average compared to HL. $\left[\mathrm{CO}_{3}^{2-}\right]$ levels did not strongly influence this proportion.

\section{Discussion and conclusions}

The observation that $\left[\mathrm{CO}_{3}^{2-}\right]$ affects the shell weight of foraminifera is consistent with previous studies (Bijma et al., 
1999, 2002; Russell et al., 2004). However, earlier work did not provide quantitative estimates of the response of foraminifera calcification to changes in seawater carbonate chemistry. The final shell weight was impacted by both the initial shell weight and the time needed until gametogenesis $(\Delta t)$. For $O$. universa, the weight of the initial shell that was calcified in the field was negligible ( $\sim 5 \%$ of final weight), whereas it was about half of the final weight for G. sacculifer. $\Delta t$ also varied under the two different light conditions used for $G$. sacculifer, with gametogenesis occurring two days earlier under high irradiance than under low irradiance. In contrast to previous estimates, the rate of calcification normalized per unit biomass was either not influenced or only slightly influenced by the initial shell size and $\Delta t$. Hence, the $\left[\mathrm{CO}_{3}^{2-}\right]$ impact on the final weight was certainly biased in G. sacculifer. Effectively calculating the rate of calcification by normalizing the mass increase by the time required to precipitate should lead to a better approximation of the $\left[\mathrm{CO}_{3}^{2-}\right]$ effect on the calcite production. To our knowledge, this is the first report providing a first order estimate of the $\left[\mathrm{CO}_{3}^{2-}\right]$ effect on calcification rates of planktonic foraminifera.

Our estimate of the calcification rate was, however, not free of biases, particularly in the case of $O$. universa. The initial shell size and survival time of this species in culture was not available and was estimated from independent observations. Therefore, the organic weight could not be calculated as the average weight during the experiment but only as a function of the final shell weight. This uncertainty influences the calcification estimates of $O$. univers $a$, but it does not affect the conclusion that calcification decreases as a function of decreasing $\left[\mathrm{CO}_{3}^{2-}\right]$ and the final weight observations. This bias does not occur with $G$. sacculifer because all the required data were available. In order to calculate the calcification rate on a cytoplasmic carbon content basis, the latter is assumed to be related to the size of the shell. Before gametogenesis, cytoplasm usually fills the final chamber entirely. This assumption did not introduce large variability. However, during collection $(t=0)$, cytoplasm may not have entirely filled the last chamber, which may explain, in part, the variability observed between individuals.

Foraminifera calcify intermittently. They calcify new chambers every few days within only a few hours (e.g., Spero, 1988; Hemleben et al., 1989). Shortly before undergoing gametogenesis, they add an additional layer of socalled gametogenic calcite, which can account for 4 to $20 \%$ of the final weight of the shell of $O$. universa (Hamilton et al., 2008). Hence, foraminiferal calcification is not a constant process, and our estimates are averages over the culture period involving primary, secondary and gametogenic calcite. If $\left[\mathrm{CO}_{3}^{2-}\right]$ affects gametogenetic calcification differently, massive addition of gametogenetic calcification may hide reduced calcification of earlier formed carbonate. $O$. universa produces a thin juvenile trochospiral test and a large thick spherical chamber at the end of its life cycle. This massive calcification is responsible for the high calcification rate calculated for this species (Fig. 3), but this rate is not representative of the calcification rate during trochospiral shell growth. It should be noted that $O$. universa produces this final spherical chamber over a period of several days of continued calcification.

Irradiance had a significant effect both on growth and calcification of G. sacculifer. At low irradiance, the time between collection and reproduction $(\Delta t)$ was shorter; furthermore the final shell weight and the rates of calcification were lower compared to high irradiance (Figs. 1-3, Table 1). Calcification was 30\% lower in LL than in HL. This is consistent with previous results on G. sacculifer (Erez, 1983) and $O$. universa (Lea et al., 1995). These studies indicated rates of calcification 3 to 4 times higher in the light than in the dark, which correspond to a 66-75\% decrease in dark conditions. Similar observations have been made on other photosynthetic calcifying organisms such as zooxanthellate corals (Gattuso et al., 1999; Moya et al., 2006; Schutter et al., 2008), which further highlights the strong interactions between irradiance and calcification rate. Planktonic foraminifera calcify mostly during daytime, and only 10 to $30 \%$ of the calcite is added during the night for $O$. universa (Lea et al., 1995). Symbiotic algae may facilitate calcification during daytime by increasing the $\mathrm{pH}$ in the vicinity of the shell (Rink et al., 1998). In contrast, the respiration process at night reduces the $\mathrm{pH}$ around the foraminifera. As a result, night calcification may be more affected by a decrease in bulk $\left[\mathrm{CO}_{3}^{2-}\right]$. At extremely low $\left[\mathrm{CO}_{3}^{2-}\right]$, night calcification may potentially stop prior to day calcification or lead to shell dissolution. Irradiance has a strong effect on the calcification under HL and only a slight effect under LL, yet the response (slope) to changes in bulk $\left[\mathrm{CO}_{3}^{2-}\right]$ was not significantly different between the two irradiance conditions. Therefore, the potential effect of $\left[\mathrm{CO}_{3}^{2-}\right]$ on dark and light calcification cannot be separated. This eventually originates from the fact that foraminifera also have the ability to control the $\mathrm{pH}$ in the seawater vacuoles used for calcification (Beentov et al., 2009; Nooijer et al., 2009).

The final shell weight (Figs. 1 and 2) and the calcification rate (Fig. 3) clearly depended on $\left[\mathrm{CO}_{3}^{2-}\right]$. In the case of LL conditions for $G$. sacculifer, the weight offset between initial and final conditions was too low to observe significant changes in final shell weight (Fig. 2b), but its calcification rate was significantly influenced by $\left[\mathrm{CO}_{3}^{2-}\right]$ (Fig. 3b). Over the full range of $\left[\mathrm{CO}_{3}^{2-}\right]$ tested, calcification rates increased between 34 and $44 \%$ for G. sacculifer and 34 to $41 \%$ for O. universa, resulting in a shell weight increase between 24 to $34 \%$ for $G$. sacculifer and 64 to $87 \%$ for $O$. universa. The potential impact of ocean acidification on foraminifera calcite production can be estimated from these results. For this purpose, we assume that in the surface ocean the current global $\left[\mathrm{CO}_{3}^{2-}\right]$ is around $200 \mu \mathrm{mol} \mathrm{kg}{ }^{-1}$ (corresponding to the year 2004), $225 \mu \mathrm{mol} \mathrm{kg}{ }^{-1}$ for the preindustrial period, $279 \mu \mathrm{mol} \mathrm{kg}^{-1}$ for the last glacial maximum (LGM) 
conditions and $110 \mu \mathrm{mol} \mathrm{kg}^{-1}$ under the IS92a "business as usual" scenario as defined by the Intergovernmental Panel on Climate Change (IPCC) and projected for the year 2100 (Orr et al., 2005). Under these conditions, the present rate of calcification of G. sacculifer and $O$. universa would be 1.5 to $3.5 \%$ lower than preindustrial values and 5 to $10 \%$ lower than during the LGM. The present calcification would yield a decrease in the final shell weight of 1.1-1.6\% (G. sacculifer $\mathrm{LL}$ and $\mathrm{HL}$ ) to 5-7\% (O. universa) compared to preindustrial conditions and 3.4-4.8\% (G. sacculifer LL and HL) to 15$20 \%$ (O. universa) compared to LGM conditions. These estimated differences between present, preindustrial and LGM foraminifera weights are in the same range of values, but they are slightly lower than the weight difference observed in sediment cores. Globigerinoides ruber is presently $11 \%$ lighter than preindustrial specimens and 20\% lighter than LGM specimens (de Moel et al., 2009). Individuals of Globigerina bulloides sampled in sediment cores exhibit a 30 to $35 \%$ decrease in weight since the LGM (Barker and Elderfield, 2002; Moy et al., 2009). Our results suggest that in 2100, the rate of calcification of $G$. sacculifer and $O$. universa could decline by 6 to $13 \%$ compared to present rates, leading to shell weight reduction of 20 to $27 \%$ for $O$. universa and 4 to $6 \%$ for G. sacculifer. The magnitude of this potential decrease is consistent with that projected for some zooxanthellate corals (Langdon and Atkinson, 2005) and oysters (Gazeau et al., 2007), but it is lower than other observations on corals (Langdon and Atkinson, 2005), mussels (Gazeau et al., 2007), or pteropods (Comeau et al., 2009). Other planktonic foraminifera may have a higher sensitivity to $\left[\mathrm{CO}_{3}^{2-}\right]$, especially those that lack photosymbionts and inhabit temperate to cold waters, which naturally have reduced concentrations of $\mathrm{CO}_{3}^{2-}$. Hence, it is possible that the decrease of $\left[\mathrm{CO}_{3}^{2-}\right]$ may have a larger effect on non-symbiotic species than on symbiotic species. This may explain the larger decrease of shell weight between LGM to modern conditions observed for the non-symbiotic species G. bulloides (Barker and Elderfield, 2002; Moy et al., 2009) compared to the symbiotic G. ruber (de Moel et al., 2009). Consequently, there is a need to assess the effect of $\left[\mathrm{CO}_{3}^{2-}\right]$ on the calcification rate of non-symbiotic species. Additionally, in order to estimate the influence of global environmental changes on calcite fluxes generated by foraminifera, there is a need to estimate the effect of reduced $\mathrm{pH}$ on shell dissolution and crust formation during sedimentation (Schiebel et al., 2007). The combined effect of decreased $\mathrm{pH}$, elevated temperature and reduced food availability also need to be estimated. At higher temperatures, large foraminifera are usually more abundant (Bé and Tolderlund, 1971), have higher growth rates (Lombard et al., 2009), and produce larger shells (Schmidt et al., 2006). Hence, the future increase in temperature could increase the production of calcite by foraminifera, counteracting the negative impact of ocean acidification. On the other hand, food availability for foraminifera could decrease in the future (Behrenfeld, 2006). As a result, foraminiferal abundance or growth rate could decline, thereby adding to the negative impact of ocean acidification. The combined effect of temperature, $\left[\mathrm{CO}_{3}^{2-}\right]$ and food availability, thus, need to be investigated in order to estimate the impact of global environmental changes on foraminiferal calcite flux.

Acknowledgements. We greatly thank the members of the Forclim Team for constructive discussions and their improvements of the manuscript, the French program ANR05-BLAN0275-01 Forclim, CEA and CNRS for their support to LSCE and the Marie Curie Intra-European Fellowship No. 221696 for funding. We also thank G. M. Ganssen, H. J. Spero and one anonymous referee who greatly improved the manuscript with their comments. FL is grateful to the Wrigley Marine Science Center for providing a field station for the experiments. For assistance in the field and laboratory, RdR and JB gratefully acknowledge A. Kuroyanagi, A. Lenderink, B. Hönisch and the staff of the Isla Magueyes Marine Laboratory of the University of Puerto Rico. We thank H. Spero for providing his equipment and Katherine French for language corrections. The work of RdR and JB was supported by the German research foundation (DFG) under grant No. BI 432/4-2 ("PaleoSalt"), and by the European Science Foundation (ESF) under the EUROCORES Programme EuroCLIMATE through contract No. ERAS-CT-2003-980409 of the European Commission, DG Research, FP6. This is a contribution to the "European Project on Ocean Acidification" (EPOCA), which receives funding from the European Community's Seventh Framework Programme (FP7/2007-2013) under grant agreement 211384 and of CARBOOCEAN (FP6/511176-2).

Edited by: W. Kiessling

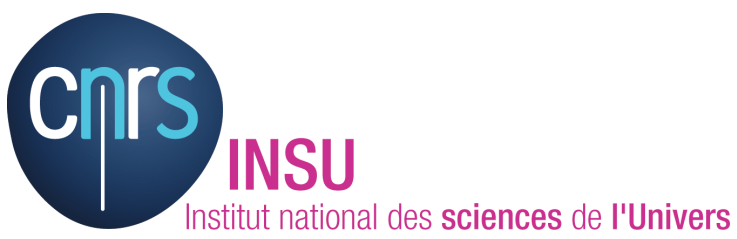

The publication of this article is financed by CNRS-INSU.

\section{References}

Armstrong, R. A., Lee, C., Hedges, J. I., Honjo, S., and Wakeham, S. G.: A new, mechanistic model for organic carbon fluxes in the ocean based on the quantitative association of POC with ballast minerals, Deep-Sea Res. II, 49, 219-236, 2002.

Barker, S. and Elderfield, H.: Foraminiferal calcification response to glacial-interglacial changes in atmospheric $\mathrm{CO}_{2}$, Science, 297, 833-836, 2002.

Bé, A. W. H. and Tolderlund, D. S.: Distribution and ecology of living planktonic foraminifera in surface waters of the Atlantic and Indian Oceans, in: Micropaleontology of Oceans, edited by: Funnell, B. M. and Riedel, W. R., Cambridge University Press, London, 105-149, 1971.

Behrenfeld, M. J., O’Malley, R. T., Siegel, D. A., McClain, C. R., Sarmiento, J. L., Feldman, G. C., Milligan, A. J., Falkowski, P. G., Letelier, R. M., and Boss, E. S.: Climate-driven trends in contemporary ocean productivity, Nature, 444, 752-755, 2006. 
Bentov, S., Brownlee, C., and Erez, J.: The role of seawater endocytosis in the biomineralization process in calcareous foraminifera, P. Natl. Acad. Sci. USA, 106, 21500-21504, 2009.

Bijma, J., Hönich, B., and Zeebe, R. E.: Impact of the ocean carbonate chemistry on living foraminiferal shell weight: Comment on "Carbonate ion concentration in glacial-age deep waters of the Caribbean Sea" by W. S. Broecker and E. Clark, Geochem. Geophy. Geosy., 3, 1064, doi:10.1029/2002GC000388, 2002.

Bijma, J., Spero, H. J., and Lea, D. W.: Reassessing foraminiferal stable isotope geochemistery: Impact of the oceanic carbonate system (experimental results), in: Uses of Proxies in Paleoceanography: Examples from the South Atlantic, edited by: Fischer, G. and Wefer, G., Springer Verlag, Berlin-Heidelberg, 489-512, 1999.

Comeau, S., Gorsky, G., Jeffree, R., Teyssié, J.-L., and Gattuso, J.P.: Impact of ocean acidification on a key Arctic pelagic mollusc (Limacina helicina), Biogeosciences, 6, 1877-1882, 2009, http://www.biogeosciences.net/6/1877/2009/.

de Moel, H., Ganssen, G. M., Peeters, F. J. C., Jung, S. J. A., Kroon, D., Brummer, G. J. A., and Zeebe, R. E.: Planktic foraminiferal shell thinning in the Arabian Sea due to anthropogenic ocean acidification?, Biogeosciences, 6, 1917-1925, 2009, http://www.biogeosciences.net/6/1917/2009/.

Dickson, A. G. and Millero, F. J.: A comparison of the equilibrium constant $\mathrm{s}$ for the dissociation of carbonic acid in seawater media, Deep-Sea Res., 34, 1733-1743, 1987.

Erez, J.: Calcification rates, photosynthesis and light in planktonic foraminifera, in: Biomineralization and biological metal accumulation, edited by: Westbroek, P. and de Jong, E. W., D. Reidel Publishing Company, Dodrecht, 307-312, 1983.

Feely, R. A., Sabine, C. L., Lee, K., Berelson, W., Kleypas, J., Fabry, V. J., and Millero, F. J.: Impact of anthropogenic $\mathrm{CO}_{2}$ on the $\mathrm{CaCO}_{3}$ system in the oceans, Science, 305, 362-366, 2004.

Gattuso, J. P., Allemand, D., and Frankignoulle, M.: Photosynthesis and calcification at cellular, organismal and community levels in coral reefs: A review on interactions and control by carbonate chemistry, Am. Zool., 39, 160-183, 1999.

Gazeau, F., Quiblier, C., Jansen, J. M., Gattuso, J. P., Middelburg, J. J., and Heip, C. H. R.: Impact of elevated $\mathrm{CO}_{2}$ on shellfish calcification, Geophys. Res. Lett., 34, L07603, doi:10.1029/2006GL028554, 2007.

Hamilton, C. P., Spero, H. J., Bijma, J., and Lea, D. W.: Geochemical investigation of gametogenic calcite addition in the planktonic foraminifera Orbulina universa, Mar. Micropaleontol., 68, 256-267, 2008.

Hemleben, C., Spindler, M., and Anderson, O. R.: Modern planktonic foraminifera, Springer-Verlag, New York, 363 pp., 1989.

Iglesias-Rodriguez, M. D., Halloran, P. R., Rickaby, R. E. M., Hall, I. R., Colmenero-Hidalgo, E., Gittins, J. R., Green, D. R. H., Tyrrell, T., Gibbs, S. J., von Dassow, P., Rehm, E., Armbrust, E. V., and Boessenkool, K. P.: Phytoplankton calcification in a high- $\mathrm{CO}_{2}$ world, Science, 320, 336-340, 2008.

Klaas, C. and Archer, D. E.: Association of sinking organic matter with various types of mineral ballast in the deep sea: Implication for the rain ration, Global Biogeochem. Cy., 16, 63-61, doi:10.1029/2001GB001765, 2002.

Langdon, C. and Atkinson, M. J.: Effect of elevated $p \mathrm{CO}_{2}$ on photosynthesis and calcification of corals and interactions with seasonal change in temperature/irradiance and nu- trient enrichment, J. Geophys. Res.-Oceans, 110, C09S07, doi:10.1029/2004JC002576, 2005.

Lea, D. W., Martin, P. A., Chan, D. A., and Spero, H. J.: Calciumuptake and calcification rate in the planktonic foraminifer $\mathrm{Orbu}$ lina universa, J. Foraminifer. Res., 25, 14-23, 1995.

Leclercq, N., Gattuso, J.-P., and Jaubert, J.: $\mathrm{CO}_{2}$ partial pressure controls the calcification rate of a coral community, Glob. Change Biol., 6, 329-334, 2000.

Lewis, E. and Wallace, D.: Program developed for $\mathrm{CO}_{2}$ system calculations, Carbon Dioxide Information Analysis Center, Oak Ridge National Laboratory, US Department of Energy, 1998.

Lombard, F., Labeyrie, L., Michel, E., Spero, H. J., and Lea, D. W.: Modelling the temperature dependent growth rates of planktic foraminifera, Mar. Micropaleontol., 70, 1-7, 2009.

Mehrbach, C., Culberson, C. H., Hawley, J. E., and Pytkowicz, R. M.: Measurement of the apparent dissociation constants of carbonic acid in seawater at atmospheric pressure, Limnol. Oceanogr., 18, 897-907, 1973.

Michaels, A. F., Caron, D. A., Swanberg, N. R., Howse, F. A., and Michaels, C. M.: Planktonic sarcodines (Acantharia, Radiolaria, Foraminifera) in surface waters near Bermuda: abundance, biomass and vertical flux, J. Plankton Res., 17, 131-163, 1995.

Moy, A. D., Howard, W. R., Bray, S. G., and Trull, T. W.: Reduced calcification in modern Southern Ocean planktonic foraminifera, Nature Geoscience, 2, 276-280, 2009.

Moya, A., Tambutte, S., Tambutte, E., Zoccola, D., Caminiti, N., and Allemand, D.: Study of calcification during a daily cycle of the coral Stylophora pistillata: implications for "light-enhanced calcification”, J. Exp. Biol., 209, 3413-3419, 2006.

Nooijer, L. J., Toyofuku, T., and Kitazato, H.: Foraminifera promote calcification by elevating their intracellular $\mathrm{pH}, \mathrm{P}$. Natl. Acad. Sci. USA, 106, 15374-15378, 2009.

Orr, J. C., Fabry, V. J., Aumont, O., Bopp, L., Doney, S. C., Feely, R. A., Gnanadesikan, A., Gruber, N., Ishida, A., Joos, F., Key, R. M., Lindsay, K., Maier-Reimer, E., Matear, R., Monfray, P., Mouchet, A., Najjar, R. G., Plattner, G. K., Rodgers, K. B., Sabine, C. L., Sarmiento, J. L., Schlitzer, R., Slater, R. D., Totterdell, I. J., Weirig, M. F., Yamanaka, Y., and Yool, A.: Anthropogenic ocean acidification over the twenty-first century and its impact on calcifying organisms, Nature, 437, 681-686, 2005.

Prentice, C., Farquhar, G. D., Fasham, M. J. R., Goulden, M. L., Heimann, M., Jaramillo, V. J., Kheshgi, H. S., Le Quéré, C., Scholes, R. J., and Wallace, D. W. R.: The carbon cycle and atmospheric carbon dioxide, in: Climate Change 2001: The Scientific Basis. Contribution of Working Group I to the Third Assessment Report of the Intergovernmental Panel on Climate Change, edited by: Houghton, J. T., Ding, Y., Griggs, D. J., Noguer, M., van der Linden, P. J., Dai, X., Maskell, K., and Johnson, C. A., Cambridge University Press, New York, 185-237, 2001.

Riebesell, U., Zondervan, I., Rost, B., Tortell, P. D., Zeebe, R. E., and Morel, F. M. M.: Reduced calcification of marine plankton in response to increased atmospheric $\mathrm{CO}_{2}$, Nature, 407, 364-367, 2000.

Rink, S., Kühl, M., Bijma, J., and Spero, H. J.: Microsensor studies of photosynthesis and respiration in the symbiotic foraminifer Orbulina universa, Mar. Biol., 131, 583-595, 1998.

Russell, A. D., Hönisch, B., Spero, H. J., and Lea, D. W.: Effects of seawater carbonate ion concentration and temperature on shell $\mathrm{U}$, $\mathrm{Mg}$, and $\mathrm{Sr}$ in cultured planktonic foraminifera, Geochim. Cos- 
mochim. Ac., 68, 4347-4361, 2004.

Sabine, C. L., Feely, R. A., Gruber, N., Key, R. M., Lee, K., Bullister, J. L., Wanninkhof, R., Wong, C. S., Wallace, D. W. R., Tilbrook, B., Millero, F. J., Peng, T. H., Kozyr, A., Ono, T., and Rios, A. F.: The oceanic sink for anthropogenic $\mathrm{CO}_{2}$, Science, 305, 367-371, 2004.

Schiebel, R., Barker, S., Lendt, R., Thomas, H., and Bollmann, J.: Planktic foraminiferal dissolution in the twilight zone, Deep-Sea Res. II, 54, 676-686, 2007.

Schiebel, R.: Planktic foraminiferal sedimentation and the marine calcite budget, Global Biogeochem. Cy., 16, 1065, doi:1010.1029/2001GB001459, 2002.

Schmidt, D. N., Lazarus, D., Young, J. R., and Kucera, M.: Biogeography and evolution of body size in marine plankton, EarthSci. Rev., 78, 239-266, 2006.
Schutter, M., Van Velthoven, B., Janse, M., Osinga, R., Janssen, M., Wijffels, R., and Verreth, J.: The effect of irradiance on longterm skeletal growth and net photosynthesis in Galaxea fascicularis under four light conditions, J. Exp. Mar. Biol. Ecol., 367, 75-80, 2008.

Spero, H. J.: Ultrastructural examination of chamber morphogenesis and biomineralization in the planktonic foraminifer Orbulina universa, Mar. Biol., 99, 9-20, 1988.

Wolf-Gladrow, D. A., Riebesell, U., Burkhardt, S., and Bijma, J.: Direct effects of $\mathrm{CO}_{2}$ concentration on growth and isotopic composition of marine plankton, Tellus B, 51, 461-476, 1999. 